Western University Scholarship@Western

Centre for the Study of International Economic

Centre for the Study of International Economic

Relations Working Papers

Relations

1985

\title{
International Factor Movements in the Presence of a Fixed Factor
}

Peter Kuhn

Ian Wooton

Follow this and additional works at: https://ir.lib.uwo.ca/economicscsier_wp

Part of the Economics Commons

Citation of this paper:

Kuhn, Peter, Ian Wooton. "International Factor Movements in the Presence of a Fixed Factor." Centre for the Study of International Economic Relations Working Papers, 8504C. London, ON: Department of Economics, University of Western Ontario (1985). 
CENTRE FOR THE STUDY OF INTERNATIONAL ECONOMIC RELATIONS

WORKING PAPER NO. $8504 \mathrm{C}$

INTERNATIONAL FACTOR MOVEMENTS IN THE PRESENCE

OF A FIXED FACTOR

\begin{tabular}{|c|c|}
\hline Peter Kuhn \\
and \\
MAR 20 1985 \\
University of Western Ontario
\end{tabular}

Ian Wooton

This paper contains preliminary findings from research work still in progress and should not be auoted without prior approval of the authors.

DEPARTMENT OF ECONOMICS

UNIVERSITY OF WESTERN ONTARIO

LONDON, CANADA

N6A 5 C 2 
First Draft:

Very Preliminary

\section{"International Factor Movements in the Presence of a Fixed Factor"}

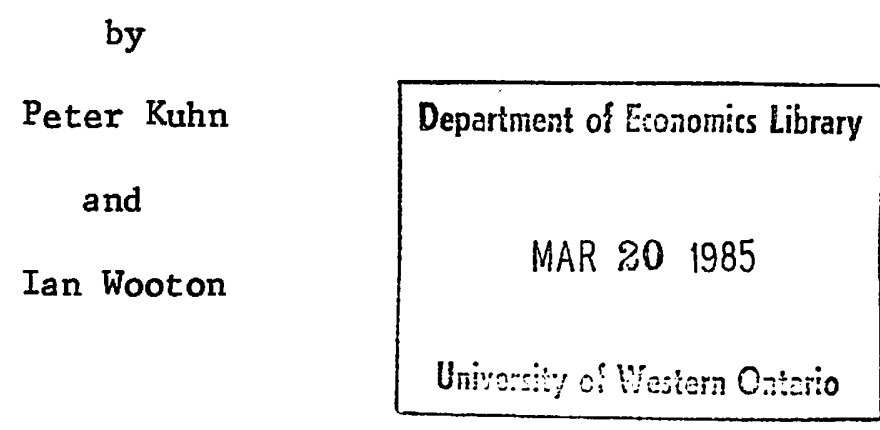

University of Western Ontario

March 1985 


\section{International Factor Movements in the Presence}

\section{of a Fixed Factor}

\section{Introduction}

Despite the well-known efficiency gains to factor mobility, considerable restrictions on factor flows currently exist between countries. These include policies such as severe restrictions on emigration (Warsaw-pact countries), capital export taxes (the US interest equalization tax (IET) and DISC programs), skill-based quota systems for immigrants, and government reviews of a11 foreign direct investments (Canada's immigration laws and Foreign Investment Review Agency (FIRA)).

One possible explanation for the existence of these restrictions is that, while lowering total world output, they represent policies which maximize the national income of the country imposing them ${ }^{1}$ (given whatever policy response, if any, is expected from other countries). If this is true, then economic theory should be able to supply a number of testable propositions concerning the incidence of mobility restrictions and their relationship to other national policies. In particular, predictions concerning the relationship between a country's relative factor endowment pattern, its relative size, its fiscal treatment of mobile factors (i.e., is it able, or does it choose to discriminate against foreign factors by paying them only their opportunity wage?), and other policies, such as its trade policy, will in principle exist.

One model which currently provides a set of predictions of this kind is so simple in structure to have earned the title of the "basic model" (Ramaswami (1968, 1970), Webb (1970), Calvo and Wellisz (1983), Bhagwati and Srinavasan (1983), Jones, Coelho, and Easton (1984)). It considers a world 
of two countries producing the same output ${ }^{2}$ using identical constant-returnsto-scale production functions with two factors, fixed in supply. The predictions of this model, while interesting, are less than satisfying for at least two reasons. First, they depend on several highly restrictive and unrealistic assumptions, including the absence of any optimizing behaviour by one of the two countries, the absence of any trade, and a set of assumptions about technology that makes it irrelevant, from a world efficiency point of view, whether production occurs in one country or the other. $^{3}$ Second, the optimal policies they predict can be so extreme-including in one case, the total absorption of one country by the other-that they do not correspond well to any observed policies. 4

This paper examines whether some of these problems with the basic model can be remedied by making one of its assumptions more realistic- namely, by introducing a third, fixed factor into the model (for example, land, climate, or a relatively immobile group of skilled workers who are a politically powerful force) that makes the physical location of the other two factors of production economically relevant. The answer to that question turns out to be both yes and no: while some of the extreme policies predicted by earlier versions of the model no longer exist, the variety of policies that are consistent with national income maximizing policy is greater than before, making the model more difficult to test.

Section 2 of the paper summarizes what is currently known about optimal labour and capital mobility in the context of the "basic model". Section 3 outlines the structure of the model, while Sections 4 and 5 describe the optimal non-discriminatory and discriminatory policies respectively. Conclusions are summarized and compared to previous results in Section 6 . 


\section{Optimal Factor Mobility in the Basic Model}

As noted above, the "basic model" of factor mobility considers a two-country world in which both countries possess identical CRS production functions, in which the "home" country actively designs policy and the foreign country remains passive, ${ }^{5}$ factor supplies are fixed, and (without loss of generality) at autarky the home country is relatively capital (K)-intensive, and the foreign country relatively labour (N)-intensive. This situation is illustrated in Figure 1, where the diagonal represents the set of world-efficient loci (embodying equal factor prices) and $E$ represents the endowment point.

If the home country is able to discriminate against foreign factors by paying them their opportunity wage, the following is known about nationalincome maximizing factor mobility policies. If only capital can move, less-than-full mobility of capital (at a point like a, where not enough capital leaves the home country to equate factor prices) is optimal. Similarly, if only labour can move, a point like $b$ is best. Simple monopoly and monopsony effects, in which trasnactions are restricted to avoid "spoiling the market", explain these results. If either capital or labour may move, but not both, Ramaswami (1968) has further shown that optimal imports of the scarce factor always dominate optimal exports of the plentiful factor (i.e., point $b$ is always preferred to point a). The intuition behind this result is that optimal (restricted) export of capital involves an efficiency loss borne by the home country--its own capital is being used more intensively abroad than at home--which does not occur when it imports labour (a11 of its own imports are then being employed at the same $\mathrm{K} / \mathrm{N}$ ratio). Finally, Jones et a1. have shown that the global optimum combination of capital and labour mobility implies not, as one might expect, some combination of 
restrictions on capital outflows and labour inflows, but instead is at point $0 *$. Thus, when discrimination is possible, the home country's optimal policy is always to import both labour and capital until the other country is completely absorbed. To see why this occurs, consider moving along a ray from $\mathrm{E}$ to $0 \%$. This leaves factor prices abroad unchanged and hence keeps foreign national income at the autarky level. The home country gains as its factor proportions move closer and closer to the world average, and it appropriates all the efficiency gains to free factor mobility at $0^{*}$, which is consistent with global efficiency. While this result is interesting, it is clearly very dependent on the assumption of CRS technologies and seems too extreme to describe any real-world policies.

If the home country cannot discriminate, and only capital is mobile, a is again the optimal point. If only labour is mobile, however, the optimum is free immigration at b. This occurs because, while each successive immigrant is paid his marginal product in the host country, his entry bids down the wages of ali previous migrants. Thus, even though the home country is "large", its national income increases monotonically with the number of immigrants. (Rather than bidding up the wages of previous immigrants, an additional immigrant now bids this wage down.) If the home country must choose between labour and capital mobility, Calvo and Wellisz have shown that now, in contrast to the discrimination case, optimal export of the plentiful factor (point a) dominates optimal import of the scarce factor (point b). Intuitively, this occurs because the home country is equally well off at $d$ as at $c$ (a. simple redrawing of national boundaries without any change in allocation shows this equivalence) where it exercises no monopoly power; restricted capital imports at point a are clearly 
better than this. Finally, Jones et al. have shown through an involved argument that, if any combination of labour and capital mobility at all can be chosen, the globally optimal policy is still at (a) (an absolute prohibition of immigration and 1 imited capital exports). The proof depends heavily on CRS, and it is interesting to ask if such an extreme policy is still predicted by a more general model.

\section{Mode1 Description}

The present model retains all the assumptions of the basic model except for the presence of a third, immobile factor. Thus we now suppose that each of two countries, home and foreign, produces the same good using three factors according to identical constant-returns-to-scale technology

$$
\begin{aligned}
& Q=F[K, N, S] \\
& Q *=F\left[K *, N^{*}, S *\right]
\end{aligned}
$$

$Q$ is the home country's output of the good, $\mathrm{K}$ (say, capital) and $N$ (say, unskilled labour) are variable factors which are internationally mobile, while S (say, skilled labour) ${ }^{6}$ is fixed in place in each country. Variables with asterisks denote the foreign-country counterparts. Each country is endowed with a stock of each factor, $\bar{K}, \bar{N}, \bar{S}$ and $\bar{K} *, \bar{N} *, \bar{S} *$. Due to the assumed immobility, $S=\vec{S}, S^{*}=\vec{S}^{*}$. The other factors will, if so permitted, migrate from one country to another until international factor prices are equalized. Let the size of the migrant population be designated by a "hat" :

$$
\begin{array}{ll}
\mathrm{K}=\overline{\mathrm{K}}+\hat{\mathrm{K}}, & \mathrm{K} *=\overline{\mathrm{K}} *-\hat{\mathrm{K}} \\
\mathrm{N}=\overline{\mathrm{N}}+\hat{\mathrm{N}}, & \mathrm{N} *=\overline{\mathrm{N}} *-\hat{\mathrm{N}}
\end{array}
$$


National income is equal to national output together with the net income of migrant factors

$$
\begin{aligned}
& Y=Q-w \hat{N}-r \hat{K} \\
& Y^{*}=Q^{*}+w \hat{N}+r \hat{K}
\end{aligned}
$$

where $\mathrm{w}$ and $\mathrm{r}$ are the factor payments made to migrant unskilled labour and capital, respectively. It is assumed that the foreign country pays all immigrants their marginal products. Thus if:

$$
\begin{array}{ll}
\hat{\mathrm{K}}<0, & \boldsymbol{x}=\mathrm{F}_{\mathrm{K}}^{*} ; \\
\hat{\mathrm{N}}<0, & \mathrm{~W}=\mathrm{F}_{\mathrm{N}}^{*} ;
\end{array}
$$

where $F_{\mathrm{K}}^{*}$ and $F_{N}^{*}$ are the partial derivatives of the foreign production function with respect to $\hat{\mathrm{K}}$ and $\hat{\mathrm{N}}$, respectively. Were the home country not to discriminate between domestically-owned and foreign-owned factors, then if:

$$
\begin{array}{ll}
\hat{\mathrm{K}}>0, & \boldsymbol{r}=\mathrm{F}_{\mathrm{K}} ; \\
\hat{\mathrm{N}}>0, & \mathrm{w}=\mathrm{F}_{\mathrm{N}} ;
\end{array}
$$

where $F_{K}$ and $F_{N}$ are the appropriate first derivatives. However, the home country may have the ability to discriminate against a factor if there is net immigration of that factor (or, perhaps, both factors) to the extent of paying the imigrant its opportunity cost, rather than its marginal product. For the factor thus discriminated against, irrespective of the pattern of International migration, either (or both) $x=\mathrm{F}_{\mathrm{K}}^{*}$ or $\mathrm{w}=\mathrm{F}_{\mathrm{N}}^{*}$.

World income is the sum of the two countries' incomes,

$$
Y^{W}=Q+Q^{*}=F[K, N, S]+F\left[K^{*}, N^{*}, S^{*}\right],
$$

and is maximized when the marginal physical products of each factor are the same in the production processes of both countries. This can be achieved 
by the free mobility of any two factors. The free mobility of one factor alone will result in the equalization of its return in both countries. However, in contrast to the "basic model", unless the other factors are being utilized in the same proportions in both the domestic country and the foreign country, the movement of the one factor will not be sufficient to yield internationally identical factor proportions and so world income would be sub-optima1. This may be illustrated in diagrams. Consider figure 2, a cuboid representing the world stock of factors. The allocation between countries may be measured with respect to the home country and foreign country origins, 0 and $0 *$, respectively. $00 *$ is the locus of combinations of factors such that each factor is used in the same proportion in production in each country $\left(\frac{\mathrm{K}}{\mathrm{K}^{*}}=\frac{\mathrm{N}}{\mathrm{N}^{*}}=\frac{\mathrm{S}}{\mathrm{S} *}\right)$. As a result, factor payments are equal across countries and hence world income must be maximized.

The fixed allocation of skilled labour between countries is known and the plane of figure 2 corresponding to that allocation is shown in figure 3. $0^{\prime} 0^{\prime}$ is the locus of identical capital-unskilled labour ratios $\left(\frac{\mathrm{K}}{\mathrm{N}}=\frac{\mathrm{K}^{*}}{\mathrm{~N}^{*}}\right)$. This line intersects at one point, $W$, with $00 *$ of figure 1 at which point capital and unskilled labour are allocated between countries in the same proportion as is skilled labour,

$$
\frac{\mathrm{K}}{\mathrm{K}^{*}}=\frac{\mathrm{N}}{\mathrm{N}^{*}}=\frac{\overline{\mathrm{S}}}{\overline{\mathrm{S}} *} .
$$

Given the international allocation of skilled labour, this is the unique point at which world income is maximized. Additionally,

$$
\begin{aligned}
& F_{N}=F_{N}^{*} \\
& F_{K}=F_{K}^{*} \\
& F_{S}=F_{S}^{*}
\end{aligned}
$$


the marginal physical products of each factor are equal internationally. If the initial allocation of capital and unskilled labour were $W$, there would be no incentive for any migration, as the rewards available abroad would be no different from those being earned at home.

Although $W$ represents the only point on the plane at which all factor prices are equalized, other points correspond to factor allocations at which the marginal product of one factor is the same in both countries. The loci of capital and unskilled labour combinations yielding the same rentals on capital in either country and the same wages to unskilled workers in either country can be derived. Wages in both countries are equalized when:

$$
\mathrm{F}_{\mathrm{N}}[\overline{\mathrm{K}}+\hat{\mathrm{K}}, \overline{\mathrm{N}}+\hat{\mathrm{N}}, \overline{\mathrm{S}}]=\mathrm{F}_{\mathrm{N}}^{*}[\overline{\mathrm{K}} *-\hat{\mathrm{K}}, \overline{\mathrm{N}} *-\hat{\mathrm{N}}, \overline{\mathrm{S}} *]
$$

Differentiating with respect to the variable factors,

$$
F_{N K} d \hat{K}+F_{N N} d \hat{N}=-F_{N K}^{*} d \hat{K}-F_{N N}^{*} d \hat{N}
$$

Thus $\left.\quad \frac{\mathrm{d} \hat{\mathrm{K}}}{\mathrm{d} \hat{N}}\right|_{\mathrm{F}_{\mathrm{N}}}=\mathrm{F}_{\mathrm{N}}^{*}=\frac{-\left(\mathrm{F}_{\mathrm{NN}}+\mathrm{F}_{\mathrm{NN}}^{*}\right)}{\left(\mathrm{F}_{\mathrm{KN}}+\mathrm{F}_{\mathrm{KN}}^{*}\right)} \geq 0$, by standard assumptions.

Similarly, rentals on capital are equalized when:

$$
F_{K}[\bar{K}+\hat{K}, \bar{N}+\hat{N}, \bar{S}]=F_{K}^{*}\left[\bar{K} *-\hat{K}, \bar{N}^{*}-\hat{N}, \bar{S} *\right] .
$$

Differentiating with respect to the variable factors,

$$
F_{K K} d \hat{K}+F_{K N} d \hat{N}=-F_{\hat{K} K}^{*} d \hat{K}-F_{K N}^{\star} d \hat{N}
$$

Using $\mathrm{F}_{\mathrm{KN}}=\mathrm{F}_{\mathrm{NK}}$ and $\mathrm{F}_{\mathrm{KN}}^{*}=\mathrm{F}_{\mathrm{NK}}^{*}$,

$$
\left.\frac{\mathrm{d} \hat{\mathrm{K}}}{\mathrm{d \hat {N }}}\right|_{\mathrm{F}_{\mathrm{K}}}=\mathrm{F}_{\mathrm{K}}^{*}=\frac{-\left(\mathrm{F}_{\mathrm{KN}}+\mathrm{F}_{\mathrm{KN}}^{*}\right)}{\left(\mathrm{F}_{\mathrm{KK}}+\mathrm{F}_{\mathrm{KK}}^{+}\right)} \geq 0
$$


Comparing the slopes of the loci,

$$
\begin{aligned}
& \left.\frac{\mathrm{d} \hat{\mathrm{K}}}{\mathrm{d} \hat{\mathrm{N}}}\right|_{\mathrm{F}_{\mathrm{K}}}=\mathrm{F}_{\mathrm{K}}^{*}=\left.\frac{\left(\mathrm{F}_{\mathrm{KN}}+\mathrm{F}_{\mathrm{KN}}^{*}\right)^{2}}{\left(\mathrm{~F}_{\mathrm{KK}}+\mathrm{F}_{\mathrm{KK}}^{*}\right)\left(\mathrm{F}_{\mathrm{NN}}+\mathrm{F}_{\mathrm{NN}}^{*}\right)} \quad \frac{\mathrm{d} \hat{\mathrm{K}}_{\mathrm{N}}^{*}}{\mathrm{~d}}\right|_{\mathrm{F}_{\mathrm{N}}}=\mathrm{F}_{\mathrm{N}}^{*} \\
& \text { At W, } \quad \frac{\left(\mathrm{F}_{\mathrm{KN}}+\mathrm{F}_{\mathrm{KN}}^{*}\right)^{2}}{\left(\mathrm{~F}_{\mathrm{KK}}+\mathrm{F}_{\mathrm{KK}}^{*}\right)\left(\mathrm{F}_{\mathrm{NN}}+\mathrm{F}_{\mathrm{NN}}^{*}\right)}=\frac{\mathrm{F}_{\mathrm{KN}}^{2}}{\mathrm{~F}_{\mathrm{KK}} \mathrm{F}_{\mathrm{NN}}}<1 \text {, by concavity. }
\end{aligned}
$$

Thus the relative slopes of the contours where they intersect is

$$
\left.\frac{\mathrm{d} \hat{\mathrm{K}}}{\mathrm{dN}}\right|_{\mathrm{F}_{\mathrm{N}}}=\mathrm{F}_{\mathrm{N}}^{*}>\left.\frac{\mathrm{d} \hat{\mathrm{K}}}{\mathrm{dN}}\right|_{\mathrm{F}_{\mathrm{K}}}=\mathrm{F}_{\mathrm{K}}^{*} \quad \geq 0
$$

They are illustrated in figure 4 , in which they form the boundaries to four zones. The relative factor payments in each zone are listed in table 1.

Table 1

$\begin{array}{llll}\text { Zone I } & \mathrm{F}_{\mathrm{N}}>\mathrm{F}_{\mathrm{N}}^{*} & \mathrm{~F}_{\mathrm{K}}>\mathrm{F}_{\mathrm{K}}^{*} & \mathrm{~F}_{\mathrm{S}}<\mathrm{F}_{\mathrm{S}}^{*} \\ \text { Zone II } & \mathrm{F}_{\mathrm{N}}<\mathrm{F}_{\mathrm{N}}^{*} & \mathrm{~F}_{\mathrm{K}}<\mathrm{F}_{\mathrm{K}}^{*} & \mathrm{~F}_{\mathrm{S}}>\mathrm{F}_{\mathrm{S}}^{*} \\ \text { Zone III } & \mathrm{F}_{\mathrm{N}}>\mathrm{F}_{\mathrm{N}}^{*} & \mathrm{~F}_{\mathrm{K}}<\mathrm{F}_{\mathrm{K}}^{*} & \mathrm{~F}_{\mathrm{S}} \gtreqless \mathrm{F}_{\mathrm{S}}^{*} \\ \text { Zone IV } & \mathrm{F}_{\mathrm{N}}<\mathrm{F}_{\mathrm{N}}^{*} & \mathrm{~F}_{\mathrm{K}}>\mathrm{F}_{\mathrm{K}}^{*} & \mathrm{~F}_{\mathrm{S}} \gtreqless \mathrm{F}_{\mathrm{S}}^{*}\end{array}$

It is clear that, unless the initial allocation is on either axis $A A^{*}$ or $\mathrm{BB}^{*}$, movement of a single factor will not be sufficient for factor price equalization. However, it is less clear that it would necessarily be in a country's best interests to have free factor mobility, with production at W. It is well known in models of international good trade that, although free trade results in the most efficient world production, it is often in the interests of an individual country to restrict trade. Similarly, succeeding sections of this paper will investigate whether a country might choose to restrict factor mobility. 
Before proceeding, however, we briefly note the substantial richness and complexity the third, immobile factor adds to the model. In the basic model, if the returns to capital were higher in one country than the other, wages had to be lower, and an adoption of free trade would lead (under standard assumptions about adjustment processes) to factor movements in opposite directions. This can happen here only in $\mathrm{Z}$ ones III and IV, which we call the "traditional" case. In the present model, the new possibility arises that both factors are cheaper or dearer in one country than the other (Zones I and II). Thus, the model can serve not only to generalize earlier results in the "traditional" case, but can analyze some entirely new issues as well, such as the optimal restrictions on both capital and labour inflows adopted by, say, a resource-rich country like Canada, that would be very difficult to generate in the "basic" framework.

\section{Non-discriminatory Policies}

The home country can limit international migration but is assumed to treat equally all factors employed in domestic production, paying them their marginal products. Factors cannot be coerced to migrate and will only be willing to move if the rewards in the other country are at least as great as in the first country. Thus the potential factor flows are determined by the initial allocation of the mobile factors between nations. Consider then the different possibilities.

4.1 Zone I. Payments to both mobile factors greater in the home country than in the foreign country. National income in the home country is

$$
Y=F[\bar{K}+\hat{K}, \bar{N}+\hat{N}, \bar{S}]-F_{K} \hat{K}-F_{N} \hat{N} \text { for } \hat{K}, \hat{N} \geq 0
$$


Consider the effect on the home country's income of permitting immigration of only one factor, say unskilled labour,

$$
\left.\frac{d Y}{d \hat{N}}\right|_{\hat{K}}=-F_{N N}\left(\hat{N}+\frac{F_{K N}}{F_{N N}} \hat{K}\right)
$$

For zero capital mobility, this has a minimum at $\hat{N}=0$. As workers enter domestic production, they are paid their marginal physical product. However, due to diminishing returns to a factor, the immigration drives down the total wage bill paid to immigrant labour, yielding benefits to the home country. Should there also be immigrant capital, the benefits of labour immigration are less unalloyed. Increasing quantities of unskilled labour in domestic production raises the productivity of other factors and so the payments to foreign capital, $F_{K} \hat{K}$, rise. Income is minimized where

$$
\hat{\mathrm{N}}=-\frac{\mathrm{F}_{\mathrm{KN}}}{\mathrm{F}_{\mathrm{NN}}} \hat{\mathrm{K}}>0 .
$$

Increasing immigration beyond this level yields higher amounts of income. However the departure of unskilled workers from the foreign country raises the wage rate. Eventually the factor payments in the two countries are driven to equality and no further migration would voluntarily occur. In Figure 5, the optimal labour immigration in the face of zero capital migration would be $\mathrm{EN}^{\prime}$.

Similarly, if only capital migrates

$$
\left.\frac{\mathrm{dY}}{\mathrm{d} \hat{\mathrm{K}}}\right|_{\hat{\mathrm{N}}}=-\mathrm{F}_{\mathrm{KK}}\left(\hat{\mathrm{K}}+\frac{\mathrm{F}_{\mathrm{KN}}}{\mathrm{F}_{\mathrm{KK}}} \hat{\mathrm{N}}\right)
$$

which has a minimum at

$$
\hat{\mathrm{K}}=-\frac{\mathrm{F}_{\mathrm{KN}}}{\mathrm{F}_{\mathrm{KK}}} \hat{\mathrm{N}}>0 .
$$


In the absence of labour mobility, national income is maximized by free immigration of capital. This is shown on Figure 5 as $\mathrm{EK}^{\prime}$.

Consider, though, the choice of the optimal combination of capital and labour immigration, given the adverse effects of immigration of one factor on the costs of the other immigrant factor's services. Even though it maximizes world income, is free mobility of both necessarily optimal from the home country's standpoint? Differentiating domestic income totally (equation 4) and setting it to zero yields the slope of equal-income contours

$$
\frac{\mathrm{d} \hat{K}_{1}}{d \hat{N} Y}=-\frac{\left(F_{N N} \hat{N}+F_{K N} \hat{K}\right)}{\left(F_{K K} \hat{K}+F_{K N N} \hat{N}\right)}
$$

Note that this is zero when equation 9 holds and is infinite when equation 11 holds. The two lines are shown on Figure 5 passing through the endowment point where, because of the concavity of the production function, the slope of $\left(\left.\frac{d Y}{d \hat{N}}\right|_{\hat{K}}=0\right)$ us greater than that of $\left(\left.\frac{d Y}{d \hat{K}}\right|_{\hat{N}}=0\right)$. Examples of equal income contours are also illustrated.

At this point, the authors are unable to determine which of three policies would yield the highest income to the home country: free labour immigration alone; free capital of immigration alone; free immigration of both factors.

4.2 Zone II. Home country factors could earn higher returns in the foreign country. National income is :

$$
\mathrm{Y}=\mathrm{F}[\overline{\mathrm{K}}+\hat{\mathrm{K}}, \overline{\mathrm{N}}+\hat{\mathrm{N}}, \overline{\mathrm{S}}]-\mathrm{F}_{\mathrm{K}}^{* \hat{K}},-\mathrm{F}_{\mathrm{N}}^{* \hat{N}} \text { for } \hat{\mathrm{N}}, \hat{\mathrm{K}} \leq 0
$$

Consider the migration of one factor, say unskilled labour, and the consequent impact on national income.

$$
\begin{array}{r}
\left.\frac{d Y}{d \hat{N}}\right|_{\hat{K}}=\left(F_{N}-F_{N}^{*}\right)+F_{N N}^{*} \hat{N}+F_{K N}^{*} \hat{K} \\
(-) \quad(+) \quad(-)
\end{array}
$$


Increasing emigration $(\hat{\mathrm{N}}<0)$ causes reduced domestic production but this is compensated for by the higher marginal product of labour abroad. However the inflow of labour to foreign production drives down the wages of existing emigrants but raises the return on any domestic capital used in foreign production. 7

Now (13) reaches a maximum at

$$
\hat{N} \equiv \frac{1}{F_{N N}^{*}}\left\{\left(F_{N}-F_{N}^{*}\right)+F_{K N}^{*} \hat{K}\right\}<0 \text {, for } \hat{K}<0
$$

If there were no capital migration, the optimal quantity of labour emigration from the country's perspective would be less than free emigration. Instead, labour would be allowed to migrate to the point at which the differential in wages for the marginal emigrant is offset by the induced reduction in the wage bill of the other migrants. If there is home country capital employed in foreign production, the optimal labour emigration will be higher, possibly being beyond the free labour mobility frontier.

Corresponding results may be found for capital mobility:

$$
\frac{\mathrm{dY}}{\mathrm{d} \hat{\mathrm{K}}_{\hat{N}}}{ }_{\hat{\mathrm{N}}}=\left(\mathrm{F}_{\mathrm{K}}-\mathrm{F}_{\mathrm{K}}^{*}\right)+\mathrm{F}_{\mathrm{KK}}^{*} \hat{\mathrm{K}}+\mathrm{F}_{\mathrm{KN}}^{*} \hat{N}
$$

with a maximum at:

$$
\hat{\mathrm{K}}=-\frac{1}{\mathrm{~F}_{\mathrm{KK}}^{*}}\left\{\left(\mathrm{~F}_{\mathrm{K}}-\mathrm{F}_{\mathrm{K}}^{*}\right)+\mathrm{F}_{\mathrm{KN}}^{*} \hat{\mathrm{N}}\right\}<0 \text {, for } \hat{\mathrm{K}}<0
$$

The slopes of equal-income contours may be calculated as:

$$
\left.\frac{d \hat{K}}{d \hat{N}}\right|_{d Y=0}=-\left\{\frac{\left(F_{N}-F_{N}^{*}\right)+F_{K N}^{*} \hat{K}+F_{N N}^{*} \hat{N}}{\left(F_{K}-F_{K}^{*}\right)+F_{K K}^{*} \hat{K}+F_{K N}^{*} \hat{N}}\right)
$$

This 15 zero when equation (15) is satisfied and is infinite when (17) holds. National income is maximized when both (15) and (17) are satisfied. 


$$
\begin{aligned}
& \stackrel{A}{K}=\frac{-F_{N N}^{*}\left(F_{K}-F_{K}^{*}\right)+F_{N K}^{*}\left(F_{N}-F_{N}^{*}\right)}{F_{K K}^{*} F_{N N}^{*}-F_{N K}^{*}{ }^{*}} \leq 0 \\
& \stackrel{A}{N}=\frac{-F_{K K}^{*}\left(F_{N}-F_{N}^{*}\right)+F_{N K}^{*}\left(F_{K}^{*}-F_{K}^{*}\right)}{F_{K K}^{*} F_{N N}^{*}-F_{N K}^{*}{ }^{*}} \leq 0
\end{aligned}
$$

a point of non-free factor mobility (except where the endowment point is at W). The solution is illustrated in Figure 6 . E is the endowment point, while $P$ is the optimal international deployment of the mobile factors, from the home country's perspective.

\subsection{Zone III. $^{8}$ Prior to any factor movements unskilled labour is paid} relatively more, and capital relatively less, in the home country than in the foreign country. National income, when labour immigrates and capital emigrates, is

$$
Y=F[\bar{K}+\hat{K}, \bar{N}+\hat{N}, \bar{S}]-F_{K}^{*} \hat{K}-F_{N} \hat{N} \text {, for } \hat{K} \geq 0, \hat{N} \leq 0
$$

capital emigration is bounded by the free-capital-mobility frontier while. the inflow of labour is bounded by the free-labour-mobility frontier.

Differentiating home country income by mobile capital yields,

$$
\left.\frac{d Y}{d \hat{K}}\right|_{\hat{N}}=\left(F_{K}-F_{K}^{*}\right)+F_{\hat{K K}}^{*} \hat{K}-F_{N K} \hat{N}
$$

For $\hat{N}$ equal to zero, income is maximized by less than free emigration of capital. As before, this results from the immiserizing effects on already emigrant capital of further emigration.

$$
\hat{\mathrm{K}}=-\frac{1}{\mathrm{~F}_{\mathrm{KK}}^{*}}\left\{\left(\mathrm{~F}_{\mathrm{K}}-\mathrm{F}_{\mathrm{K}}^{*}\right)-\mathrm{F}_{\mathrm{NK}} \hat{\mathrm{N}}\right\}
$$

The departure of capital from the home country makes domestic production relatively more labour-intensive, lowering the marginal product of immigrant unskilled workers, and thereby reducing their cost to the country. Ihus, as Jones et a1. noted in the basic model, the capital emigration has two offsetting "terms of trade" effects. 
Differentiating (21) with respect to labour immigration yields:

$$
\left.\frac{\mathrm{dY}}{\mathrm{d} \hat{N}}\right|_{\hat{\mathrm{K}}}=\mathrm{F}_{\mathrm{NK}}^{\mathrm{K}} \hat{\mathrm{K}}-\mathrm{F}_{\mathrm{NN}} \hat{\mathrm{N}}
$$

When there has been no capital movement, income is minimized with zero inflow of unskilled workers and is unconstrained as immigration increases. However the immigration of labour makes foreign production increasingly capital intensive, reducing earnings of any of the home country's capital employed abroad. Therefore, the minimum-income level of labour-immigration is:

$$
\hat{\mathrm{N}}=\frac{\mathrm{F}_{\mathrm{NK}}^{*}}{\mathrm{~F}_{\mathrm{NN}}} \hat{\mathrm{K}}>0 \text {, if } \hat{\mathrm{K}}<0
$$

Equal-income contours have slope

$$
\left.\frac{d \hat{K}}{d \hat{N}}\right|_{d Y=0}=\frac{F_{N N} \hat{N}-F_{K N}^{*} \hat{K}}{\left(F_{K}-F_{K}^{*}\right)+F_{K K}^{*} \hat{K}-F_{K N} \hat{N}}
$$

This is zero when (25) holds and infinite when (23) holds. Some are illustrated in Figure 7. The directions of increasing income are indicated by arrows. Income is maximized either by permitting free immigration of unskilled labour (point $N^{\prime}$ ) alone or by allowing the optimal emigration of capital alone (such that (23) is satisfied). Unlike the basic model, where optimal emigration of capital was preferred to point $N^{\prime}$, it appears impossible at this stage to rank these two alternatives unambiguously.

\section{Discriminatory Policies}

For simplicity, we assume throughout that the home country can discriminate against both of the immigrant factors by paying them the factor payments made in the foreign country while paying their native factors the (higher) marginal physical product in domestic production. ${ }^{9}$ Thus migrant factors will in all cases be paid their marginal products in foreign production irrespective of the flow of migration. National income is therefore always 


$$
\begin{aligned}
& Y=F[\bar{K}+\hat{K}, \bar{N}+\hat{N}, \bar{S}]-F * \hat{K}-F * \hat{N} \\
& \left.\frac{d Y}{d \hat{N}}\right|_{\hat{K}}=\left(F_{N}-F_{N}^{*}\right)+F_{N N}^{*} \hat{N}+F_{N K}^{*} \hat{K} \\
& \left.\frac{\mathrm{dY}}{\mathrm{d} \hat{\mathrm{K}}}\right|_{\hat{\mathrm{N}}}=\left(\mathrm{F}_{\mathrm{K}}-\mathrm{F}_{\mathrm{K}}^{*}\right)+\mathrm{F}_{\mathrm{KK}}^{*} \hat{\mathrm{K}}+\mathrm{F}_{\mathrm{NK}}^{*} \hat{\mathrm{N}}
\end{aligned}
$$

As a factor moves internationally, it captures the difference between its marginal product in the two countries but depresses the payments made to other factors of the same type; its impact on the other mobile factor depends on the direction of the migration flow. That is, national income may rise more or may rise less as a result of the induced change in the other factor's terms of trade.

National income is maximized when capital and labour migration amount



$$
\begin{aligned}
& \hat{K}=\frac{-F_{N N}^{*}\left(F_{K}-F_{K}^{*}\right)+F_{N K}^{*}\left(F_{N}^{*}-F_{N}^{*}\right)}{F_{N N}^{*} F_{K K}^{*}-F_{N K}^{*}{ }^{2}} \\
& \stackrel{k}{N}=\frac{-F_{k K}^{*}\left(F_{N}-F_{N}^{*}\right)+F_{N K}^{*}\left(F_{K}^{*}-F_{K}^{*}\right)}{F_{N N}^{*} F_{K K}^{*}-F_{N K}^{*}{ }^{2}}
\end{aligned}
$$

In zone $I$, where the marginal products of both factors mobile in the home country are greater than in the foreign country, and in zone II, where the opposite is the case, the optimal policy would be to restrict migration of both factors.

For the other two zones, where in each country the marginal product of one of the mobile factors is relatively higher than in the other country, this need not be the case. If the cross marginal products ( $F_{N K}^{*}$ ) were negligible, then the optimal policy would always be to restrict migration. However, sufficiently large cross-products might offset the factor's own terms' of trade effect (by 
causing a relatively greater change in the other factor's terms of trade) such that the best policy would be to permit free migration of one or both factors.

Unlike the Jones et al. result, for the basic model, the optimal policy will not in general result in an import of all the other country's factors. This is because, in their model, $0 *$ ' was consistent with world efficiency and allowed the home country to appropriate all the gains from efficient world production. Here, movements from $W$ towards 0 *' can conflict with world efficiency, resulting in a complex interaction of efficiency and terms-of-trade effects. In fact, it is easy to generate numerical examples in which the optimal factor mobility policy from point $E$ involves importing both factors, importing labour and exporting capital, and indeed exporting both factors. The only possibility that can be ruled out is emigration of $\mathrm{N}$ and immigration of $\mathrm{K}$; the authors hope soon to develop conditions under which the various directions of optimal factor flows will arise.

6. Summary and Conclusions

The addition of a third, immobile factor adds considerable richness to the basic model of international factor mobility. Entirely new cases of policy, such as optimal restrictions of both capital and labour imports (exports) by a resource-rich (poor) country, which were incompatible with the basic model, now arise. As well, analysis of the "traditional case" (one country is labour-rich, the other capital-rich) becomes more realistic when the fixed factor is added. It is no longer in the interest of an active country which can discriminate against foreign factors to employ all of the other country's factors; a wide variety of optimal policies, including emigration of both 
factors from the active country, is now possible. In the case where discrimination is not possible, the only change to the conclusions appears to be that, while the solution can still be shown to involve optimal mobility of one factor alone, it is no longer possible to determine unambiguously whether emigration of the plentiful factor or immigration of the scarce factor is preferred. 


\section{Footnotes}

${ }^{1}$ Alternative hypotheses are that distributional effects of factor mobility are also considered by the policy-making country, or that it is domestic, rather than national income, that matters to the formulators of national policy. Relevant to the latter possibility is the literature on the "brain drain" (e.g., Berry and Soligo (1969), Bhagwati and Hamada (1979), and Rivera-Batiz (1982)), which considers effects of emigration on the income of remaining residents.

2This, of course, makes trade in products irrelevant. The interaction between trade and factor mobility policies has been developed by Kemp (1966), Jones (1967), Brecher (1982), and Wong (1983), among others.

${ }^{3}$ As Iong as factor proportions are equalized in the two countries, world output is invariant to where production takes place.

${ }^{4}$ Short, of course, of territorial conquest. This is, however, somewhat incongruous with the model's assumption of a minimum, autarky consumption level for the "passive" country.

${ }^{5}$ Not only does this country never restrict factor flows, it also never discriminates against any foreign factors by only paying them their opportunity wage.

6articularly when comparing the conclusions of this model to the "basic" one, it may be more helpful to think of $S$ as "land", and $K$ and $N$ as capital and labor, respectively. We shall at times use this nomenclature.

${ }^{7}$ Jones et al termed the gain from differences in marginal products the "volume of trade" effect' and the fall in return to the emigrant factor the '"terms of trade" effect'. Note that there is here an additional "terms of trade" effect resulting from the impact of labor migration on the return to capital. 
${ }^{8}$ Analysis of Zone IV would be symmetrical to that of Zone III and so, for the sake of brevity, is omitted.

${ }^{9}$ Note that, in zone I, another possibility arises: the home country may be able to discriminate against immigrant capital but not against immigrant labor (or vice versa). Preliminary analysis of this case in an earlier draft of this paper shows that free immigration of labor (capital), combined with restricted, positive immigration of capital (labor) is the optimal policy here. 


\section{References}

Berry, R. A. and R. Soligo. "Some Welfare Aspects of International Migration," Journal of Political Economy, Sept/Oct., 1969.

Bhagwati, J. N. and K. Hamada. "The Brain Drain, International Integration of Markets for Professionals, and Unemployment: A Theoretical Analysis," Journal of Development Economics, June 1974, pp. 19-42.

Bhagwati, J. N. and T. N. Srinivasan. "On the Choice Between Capital and Labor Mobility," Journal of International Economics, 1983, pp. 209-221 . Brecher, R. "Second-Best Policy for International Trade and Investment," Journal of International Economics, November 1982.

Calvo, G. and S. Wellisz. "International Factor Mobility and the National Advantage," Journal of International Economics, 1983, pp. 103-114.

Jones, R. "International Capital Movements and the Theory of Tariffs and Trade," Quarterly Journal of Economics, February 1967, pp. 1-38.

Jones, R., I. Coelho and S. Easton. "The Basic Model in the Theory of International Factor Flows," mimeo, 1984.

Kemp, M. "The Gain from International Trade and Investment: A Neo-Hecksher-Ohlin Approach," American Economic Review, September 1966, pp. 788-809.

Ramaswami, V. K. "International Factor Movement and the National Advantage," Economica, 1968, pp. 309-310.

Ramaswami, V. K. "Reply," Economica, February 1970.

Rivera-Batiz, F. "International Migration, Non-Traded Goods, and Economic

Welfare in the Source Country," Journal of Development Economics, 1982 , Pp. $81-90$.

Ruffin, R. J. "International Factor Movements" in R. Jones and P. Kenen (eds.), Handbook of International Economics, Vol. 1 (Amsterdam: North-Holland, 1984). 
Webb, L. R. "International Factor Movement and the National Advantage: Comment," Economica, 1970, pp. $81-84$.

Wong, K. "On Choosing Among Trade in Goods and International Capital and Labor Mobility: A Theoretical Analysis," Journal of International Economics, 1983, pp. 223-250. 


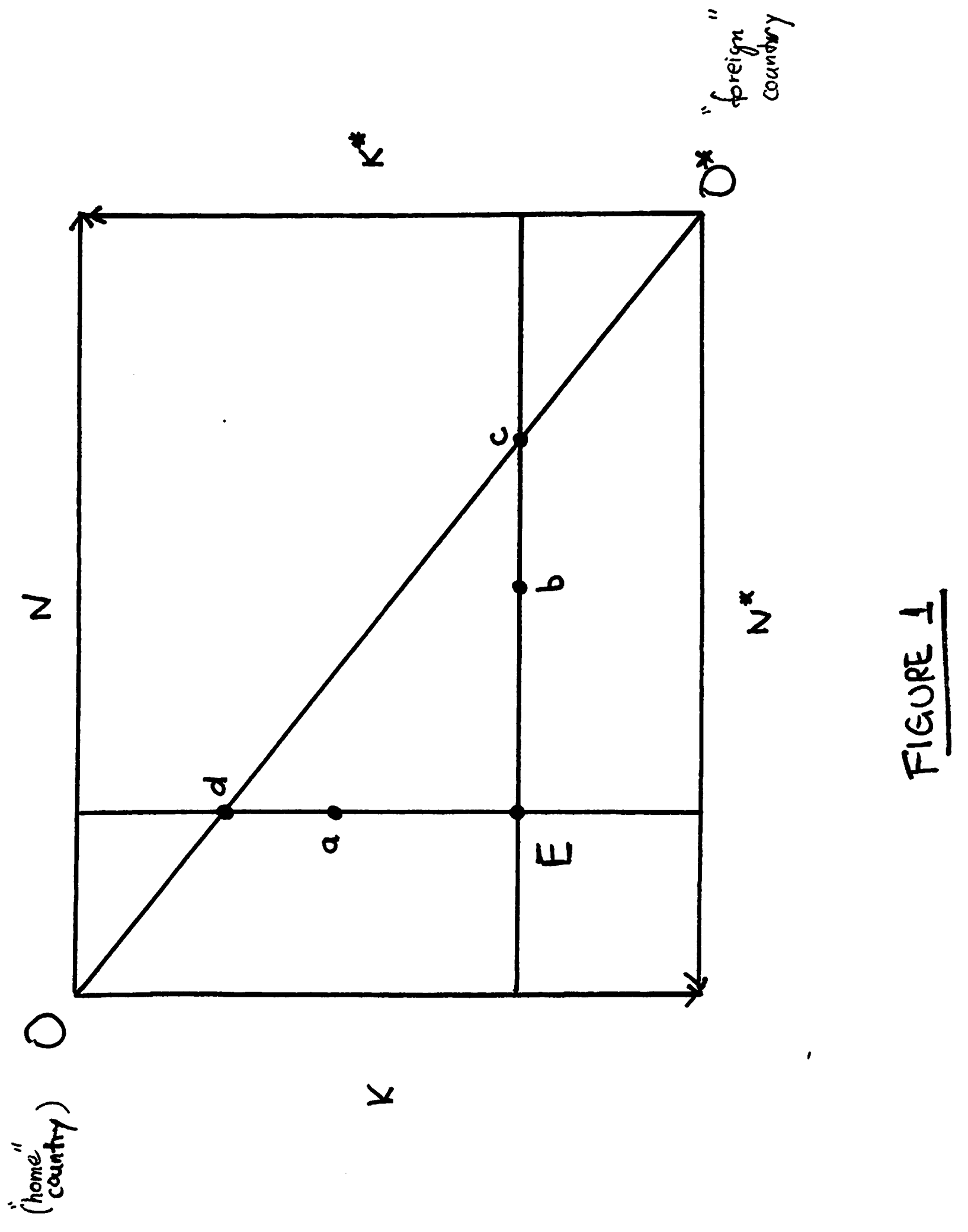




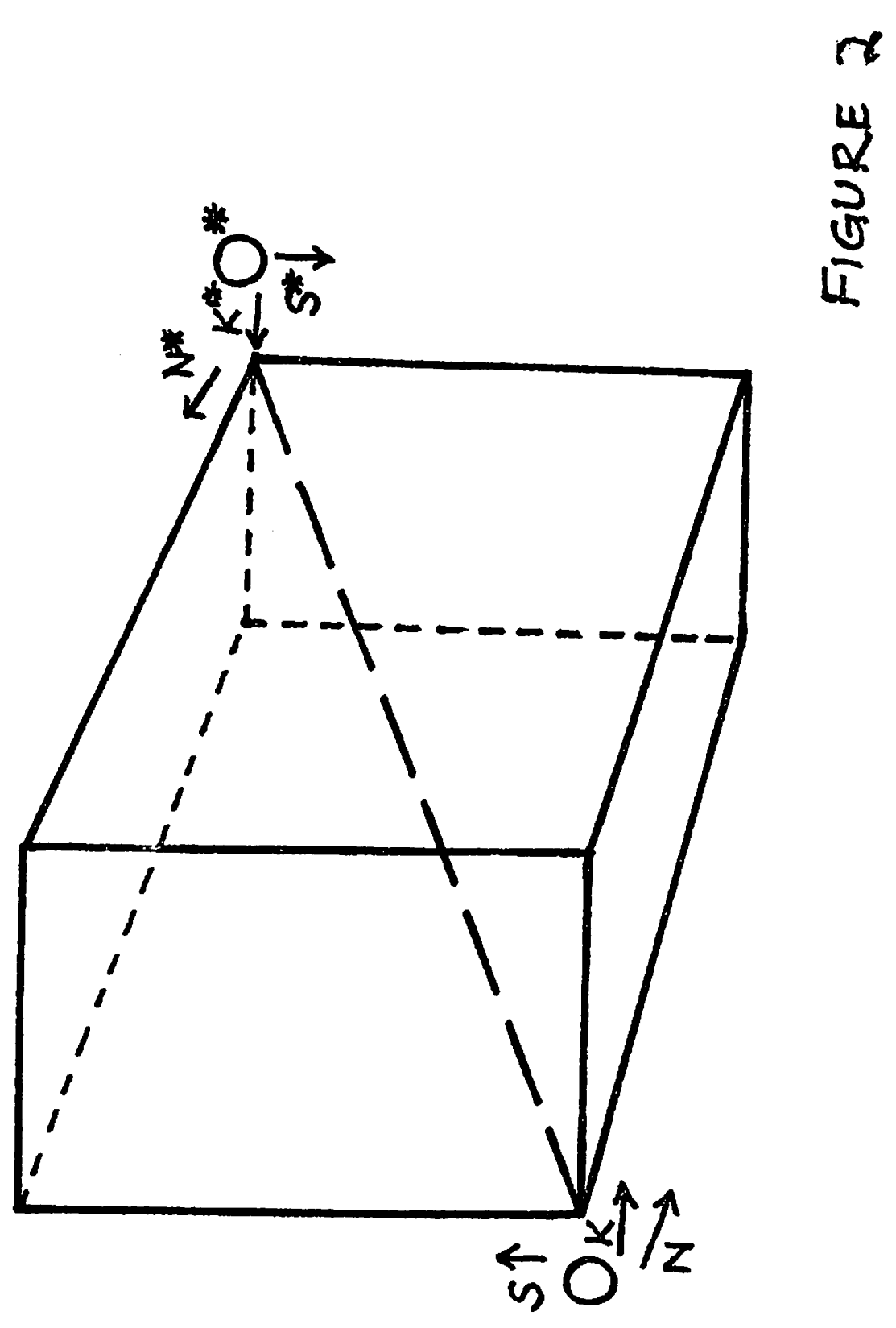




$$
\not Z_{i}
$$




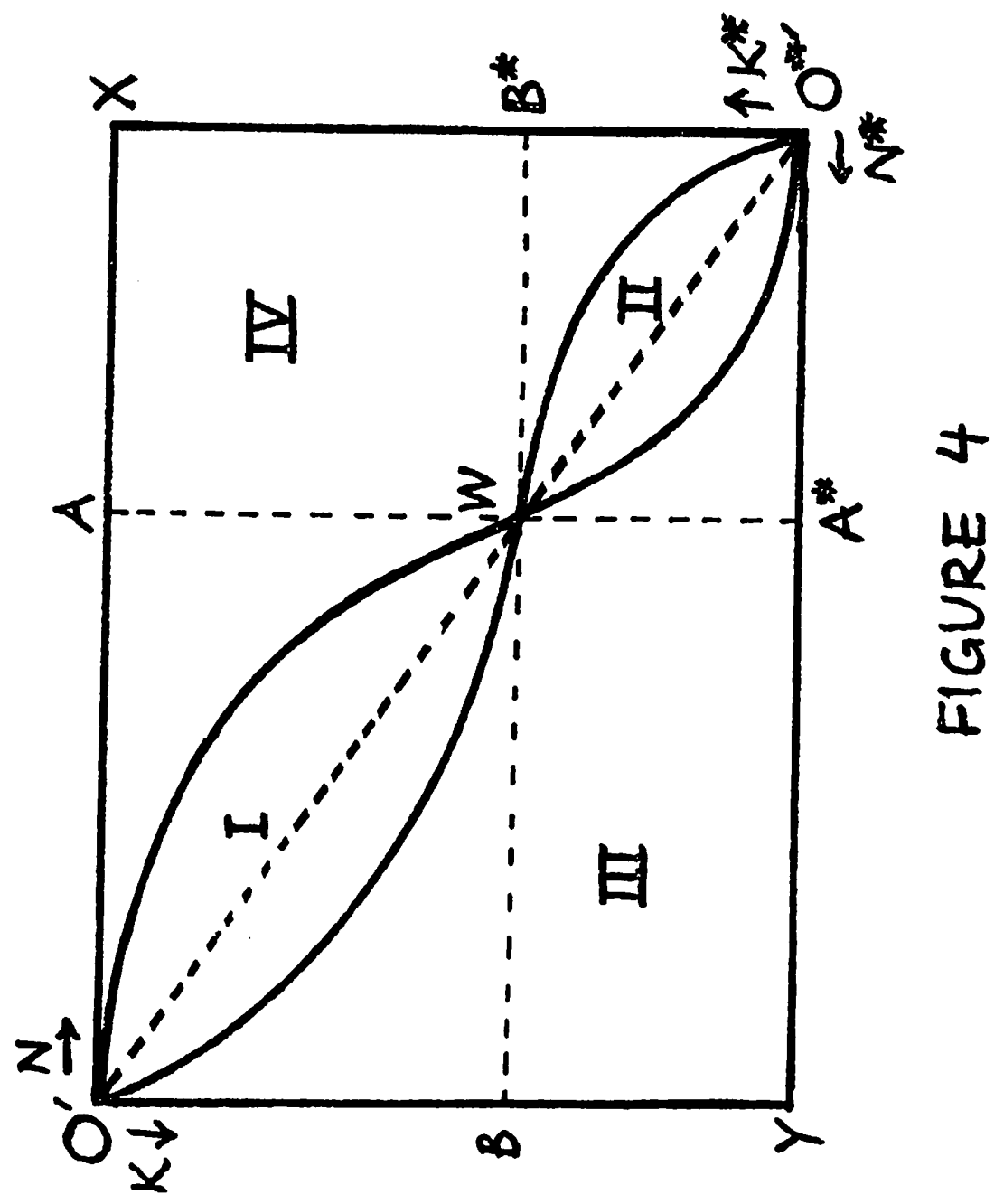




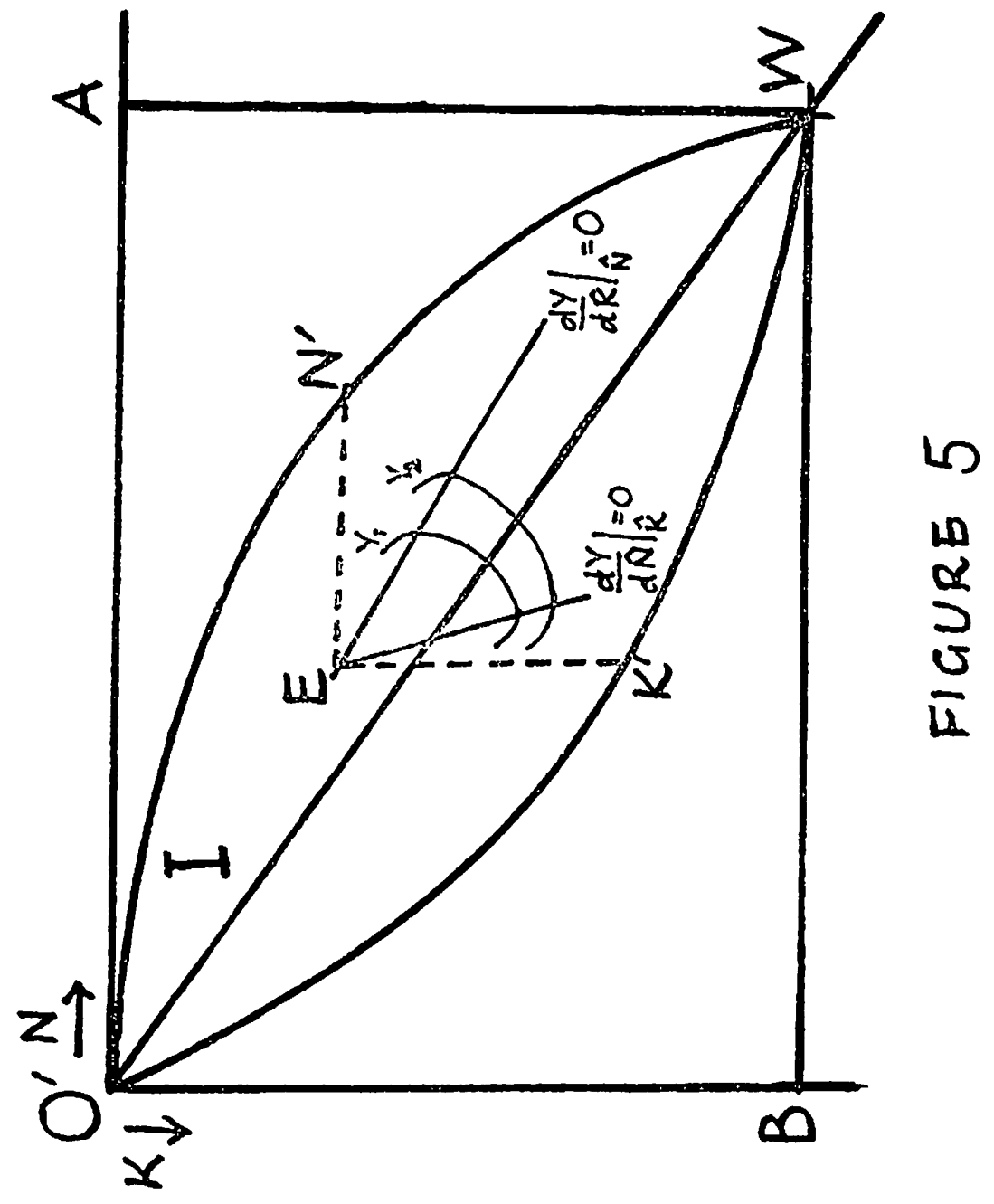




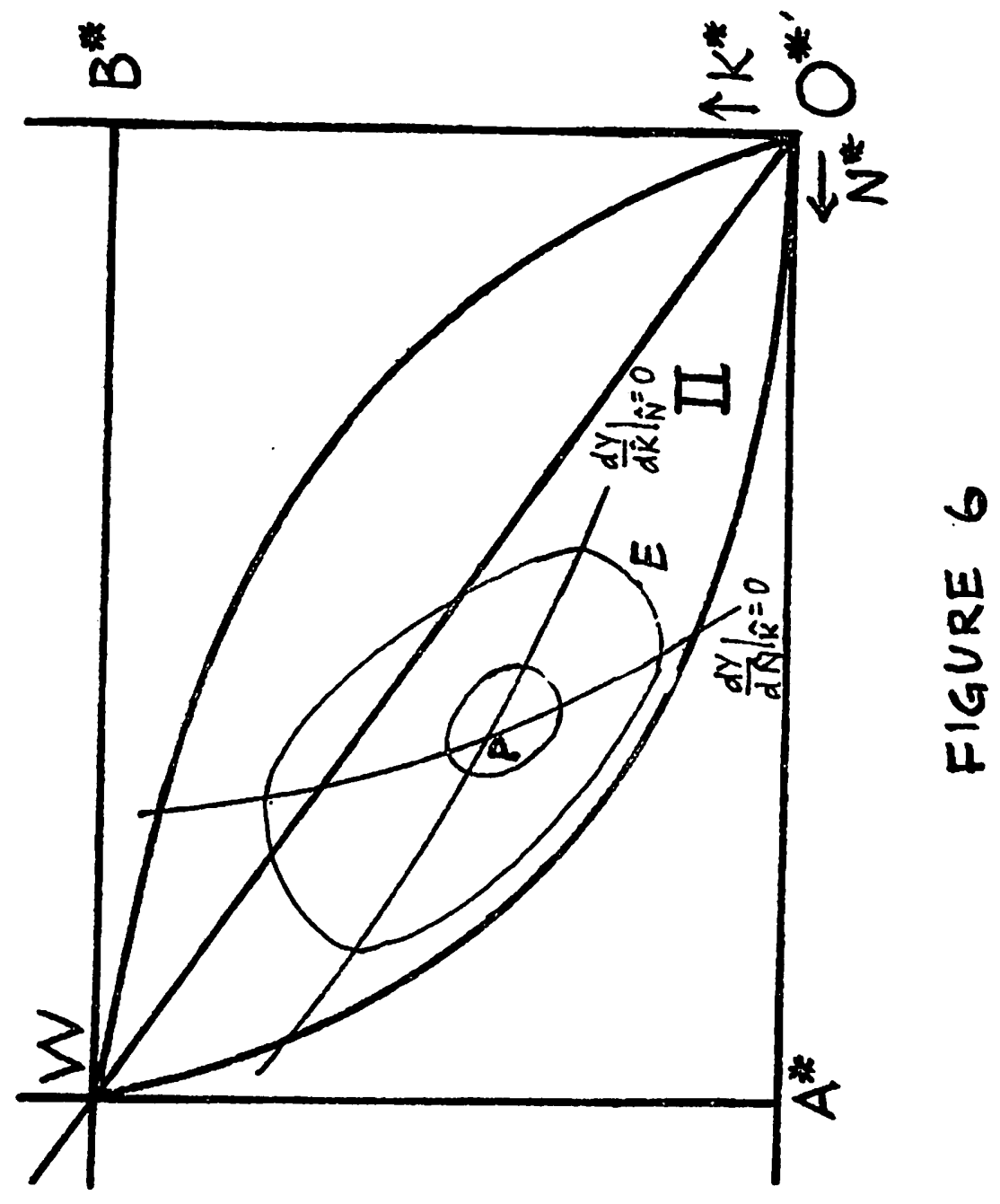




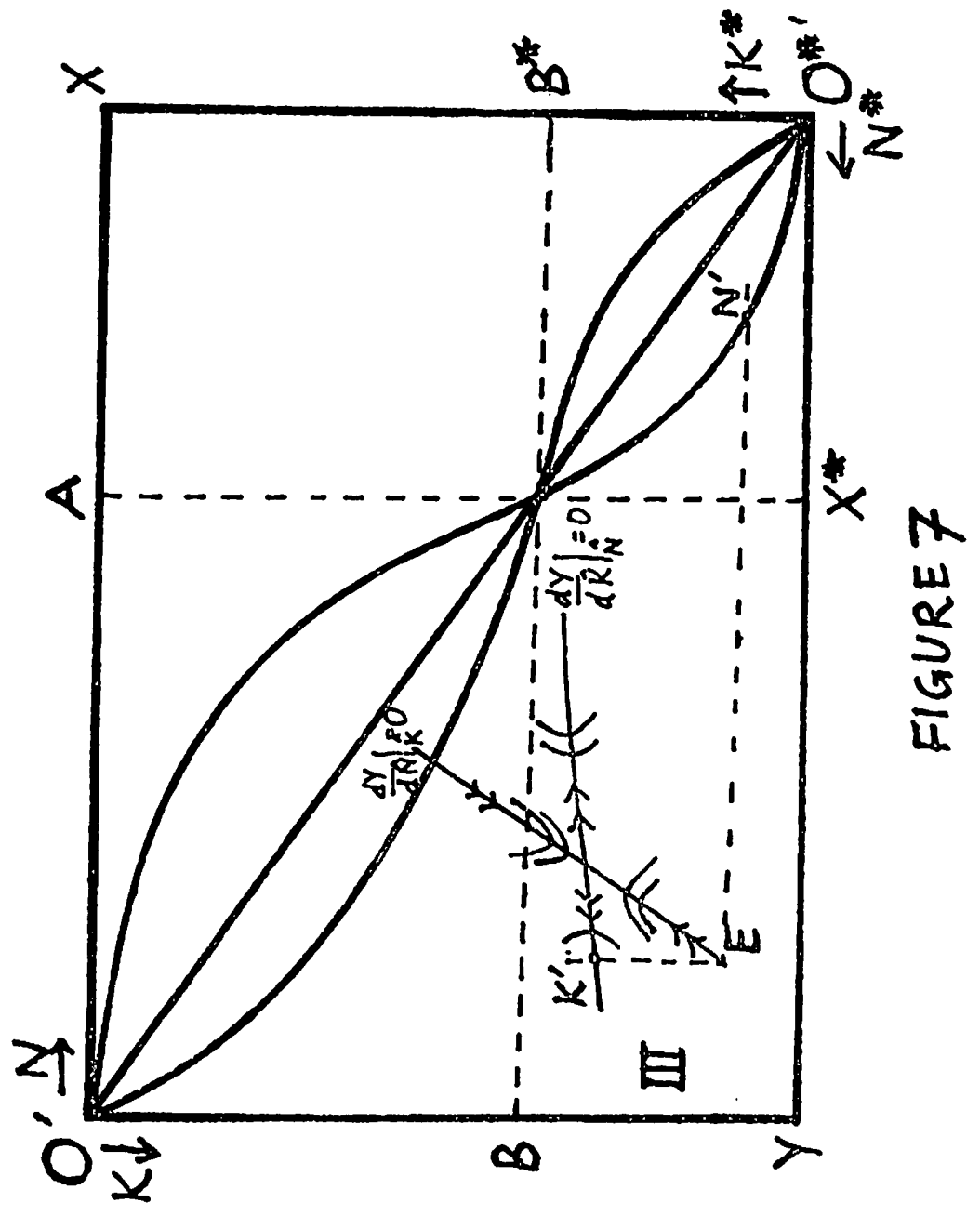


$8101 C$

$8102 C$.

$8103 C$

$8104 C$

$8105 \mathrm{C}$

$8106 \mathrm{C}$

$8107 \mathrm{C}$

8108C D gI

8109C D S

$8110 \mathrm{C}$

$8111 \mathrm{C}$

$8201 C$

$8202 C$

$8203 C$

$8204 \mathrm{C}$

$8205 C$

8206C

$8207 \mathrm{C}$

$8208 \mathrm{C}$

8209C DSU

Markusen, James R. Factor Movements and Commodity Trade as Compliments: A survey of some Cases.

Conlon, R.M. Comparison of Australian and Canadian Manufacturing Industries: Some Empirical Evidence.

Conlon, R.M. The Incidence of Transport Cost and Tariff Protection: Some Australian Evidence.

Laidler, David. On the Case for Gradualism.

Wirick, Ronald G. Rational Expectations and Rational

Stabilization Policy in an Open Economy

Mansur, Ahsan and John Whalley Numerical Specification of Applied

General Equilibrium Models: Estimation, Calibration, and Data.

Burgess, David F., Energy Prices, Capital Formation, and Potential GNP

Jimenez, E. and Douglas $\mathrm{H}$ Keare. Housing Consumption and Income in the Low Income Urban Setting: Estimates from Panel Data in El Silvador

Whalley, John Labour Migration and the North-South Debate:

Manning, Richard and John McMillan Government Expenditure and Comparative Advantage

Freid, Joel and Peter kowitt Why I nflation Reduces Real Interest Rates

\section{$\underline{1982}$}

Manning, Richard and James R. Markusen Dynamic Non- Mustitution and Long Run Production Possibilities

Feenstra, Robert and Ken Judd Tariffs, Technology Transfer, and Welfare

Ronald $w$. Jones, and Douglas D. Purvis: International Differences in Response to Common External hocks: The Role of Purchasing Power Parity

James A Brander and Barbara J. Spencer: I ndustrial Strategy with Conmitted Firms

Whalley, John, The North-South Debate and the Terms of Trade: An Applied General Equilibrium Approach

Roger Betancourt, Christopher Clague, Arvind Panagariya CAPI TAL UTI LIZATI ON IN GENERAL EQUIIIBRIUM

Mansur, Ahsan $H$ On the Estimation of Import and Export Demand Elasticities and Elasticity Pessimism.

Whalley, J. and Randy Wigle PRICE AND QUANTITY RIGIDITIES IN ADJUSTMENT TO TRADE POLICY CHANGES: ALTERNATIVE FORMULATIONS AND INITIAL CALCULATIONS

Jimenez, E. SQUATTING AND COMMUNTTY ORGANIZATION IN DEVELOPING COUNTRIES: A CONCEPTUAL FRAMEWORK 
8210C Grossman, G.M. INTERNATIONAL COMPETITION AND THE UNIONIZED SECTOR

$8211 \mathrm{C} L a 1 d l e r, D$. FRIEDMAN AND SCHWARTZ ON MONETARY TRENDS - A REVIEW ARTICLE

8212C Imam, M.H: and Whalley, J. INCIDENCE ANALYSIS OF A SECTOR SPECIFIC MINIMUM
WAGE IN A TWO SECTOR HARRIS-TODARO MODEL.

8213C Markusen, J.R. and Melvin, J.R. THE GAINS FROM TRADE THEOREM WITH INCREASINC
RETURNS TO SCALE.

8214C INDUSTRIAL ORGANILAATION AND THE GENERAL EQUILIBRIUM COSTS OF PROTECTION IN
SMALL OPEN ECONOMIES.

8215C Laldler, D. DID MACROECONOMICS NEED THE RATIONAL EXPECTATIONS REVOLUTION? 8216C Whalley, J. and WIgle, R. ARE DEVELOPED COUNTRY MULTILATERAL TARIFF
REDUCTIONS NECESSARILY BENEFICIAL FOR THE U.S.?

$8217 \mathrm{C}$ Bade, $R$. and Parkin, M. IS STERLING M3 THE RIGHT AGGREGATE?

$8218 \mathrm{C}$ Kosch, B. FIXED PRICE EQUIIIBRIA IN OPEN ECONOMIES.

1983

$8301 C$ KImbel1, L.J. and Harrison, G.W. ON THE SOLUTION OF GENERAL EQUILIBRIUM

8302C Melvin, J.R. A GENERAL EQQUILIBRIUM ANALYSIS OF'.CANADIAN OIL POLICY.



8304C Mohammad, S. Whalley, J. RENT SEEKING IN INDIA: ITS COSTS AND POLICY
SIGNIFICANCE.

8305C DSU Jimenez, E. TENURE SECURITY AND URBAN SQUUATING.

8306C Parkin, M. WHAT CAN MACROECONOMIC THEORY TELL US ABOUT THE WAY DEFICITS
SHOULD BE MEASURED.

8307C Parkin, M. THE INFLATION DEBATE: AN ATTEMPT TO CLEAR THE AIR.

8308C Wooton, I. LABOUR MIGRATION IN A MODEL OF NORTH-SOUTH TRADE.

$8309 \mathrm{C}$ Deardorff, A.V. THE DIRECTIONS OF DEVELOPING COUNTRIES TRADE: EXAMPLES
FROM PURE THEORY.

8310C Manning, $R$. ADVANTAGEOUS REALLOCATIONS AND MULTIPLE EQUILIBRIA: RESULTS
FOR THE THREE-AGENT TRANSFER PROBLEM. 
831 IC DSU Mohammad, S. and Whaliey, J. CONTrOLS AND THE INTERSECTORAL TERMS OF TRADE IN INDIA.

8312C . Brecher, Richard A. and Choudhr1, Ehsan U. NEW PRODUCTS AND THE FACTOR CONTENT OF INTERNATIONAL TRADE.

$8313 C$ Jones, R.W., Neary, J.P. and Ruane, F.P. TWO-WAY CAPITAL FLOWS: CROSSHAULING IN A MDDEL OF FOREIGN INVESTMENT.

$8314 C$ DSU Follain, J.R. Jr. and Jimenez, E. THE DEMAND FOR HOUSING CHARACTERISTICS IN DEVELOPING COUNTRIES.

8315C Shoven, J.B. and Whalley, J. APPLIED' GENERAL EQUILIBRIUM MODELS OF TAXATION AND INTERNATIONAL TRADE.

$8316 \mathrm{C}$ Boothe, Paul and Longworth David. SOME IRREGULAR REGULARITIES IN THE CANADIAN/U.S. EXCHANGE MARKET.

$8317 \mathrm{C}$ Hamilton, Bob and Whalley, John, BORDER TAX ADJUSTMENTS AND U.S. TRADE.

8318C Neary, J. Peter, and Schweinberger, Albert G. FACTOR CONTENT FUnCTIONS AND THE THEORY OF INTERNATIONAL TRADE.

8319C Veall, Michael R. THE EXPENDITURE TAX AND PROGRESSIVITY.

8320C Melvin, James R. DOMESTIC EXCHANGE, TRANSPORTATION COSTS AND INTERNATIONAL TRADE.

8321C Hamilton, Bob and Whalley, John. GEOGRAPHICALLY DISCRIMINATORY TRADE ARRANGEMENTS.

8322C Bale, Harvey Jr. INVESTMENT FRICTIONS AND OPPORTUNITIES IN BILATERAL U.S.-CANADIAN TRADE RELATIONS.

$8323 \mathrm{C}$ Wonnacott, R.J. CANADA-U.S. ECONOMIC RELATIONS-A CANADIAN VIEW.

8324C Stern, Robert M. U.S.-CANADIAN TRADE AND INVESTMENT FRICTIONS: THE U.S: VIEW.

8325C Harrison, Glenn, H. and Kimbell, Larry, J. HOW ROBUST IS NUMERICAL GENERAL EQUILIBRIUM ANALYSIS?

8326C Wonnacott, R.J. THE TASK FORCE PROPOSAL ON AUTO CONTENT: WOULD THIS SIMPLY EXTEND THE AUTO PACT, OR PUT IT AT SERIOUS RISK?

8327C Bradford, James C. CANADIAN DEFENCE TRADE WITH THE U.S. Conklin, David. SUBSIDY PACTS.

Rugman, Alan M. THE BEHAVIOUR OF U.S. SUBSIDARIES IN CANADA:

IMPLICATIONS FOR TRADE AND INVESTMENTS. 


\begin{abstract}
1983
8328C Boyer, Kenneth D. U.S.-CANADIAN TRANSPORTATION ISSUES.

$8329 \mathrm{C}$ BIrd, RIchard $M$. and Brean, Donald J.S. CANADA-U.S. TAX RELATIONS: ISSUES AND PERSPECTIVES.

$8330 \mathrm{C}$ Moroz, Andrew R. CANADA-UNITED STATES AUTOMOTIVE TRADE AND TRADE POLICY ISSUES.

8331C Grey, Rodney de C. and Curt18, John. INSTITUTIONAL ARRANGEMENTS FOR U.S.-CANADIAN NEGOTIATIONS. PART I: CANADA-U.S. TRADE AND ECONOMIC ISSUES: DO WE NEED A NEW INSTITUTION? PART II: INSTITUTIONAL ARRANGEMENTS FOR MANAGING THE CANADA-U.S. ECONOMIC RELATIONSHIP.
\end{abstract}

$\underline{1984}$

$8401 \mathrm{C}$ Harrison, Glenn W. and Manning, Richard. BEST APPROXIMATE AGGREGATION OF INPUT-OUTPUT SYSTEMS.

8402C Parkin, Michael. CORE INFLATION: A REVIEW ESSAY.

$8403 \mathrm{C}$ Blomqvist, $\dot{k}$ ke, and McMahon, Gary. SIMULATING COMMERICAL POLICY IN A SMALL, OPEN DUAL ECONOMY WITH URBAN UNEMPLOYMENT: A GENERAL EQUILIBRIUM APPROACH.

8404C Wonnacott, Ronald. THE THEORY OF TRADE DISCRIMINATION: THE MIRROR IMAGE OF VINERIAN PREFERENCE THEORY?

8405C Whalley, John. IMPACTS OF A 50\% TARIFF REDUCTION IN AN EIGHT-REGION GLOBAL TRADE MODEL.

8406C Harrison, Glenn W. A GENERAL EQUILIBRIUM ANALYSIS OF TARIFP REDUCTIONS.

$8407 \mathrm{CH}$ Horstmann, Ignatius and Markusen, James R. STRATEGIC INVESTMENTS AND THE DEVELOPMENT OF MULTINATIONALS.

8408C Gregory, Allan W. and McCurdy, Thomas H. TESTING THE UNBIASEDNESS HYPOTHESIS IN THE FORWARD FOREIGN EXCHANGE MARKET: A SPECIFICATION ANALYSIS.

$8409 \mathrm{C} J o n e s$, Ronald $\omega$. and Klerzkowsk1, Henryk. NEIGHBORHOOD PRODUCTION STRUCTURES WITH APPLICATIONS TO THE THEORY OF INTERNATIONAL TRADE.

$8410 \mathrm{C}$ Weller, Paul and Yano, Makoto. THE ROLE OF FUTURES MARKETS IN INTERNATIONAL TRADE: A GENERAL EỌUILIBRIUM APPROACH.

$8411 \mathrm{C}$ Brecher, Richard A. and Bhagwat1, Jagdish N. VOLUNTARY EXPORT RESTRICTIONS VERSUS IMPORT RESTRICTIONS: A WELFARE-THEORETIC COMPARISON. 
8412C Ethier, W1lfred J. ILLEGAL IMMIGRATION.

8413C Eaton, Jonathon and Gene M. Grossman. OPTIMAL TRADE AND INDUSTRIAL POLICY UNDER OLIGOPOLY.

8414C Hooton, Ian. PREFERENTIAL TRADING AGREEMENTS - A 3xn MODEL.

8415C Parkin, Michael. DISCRIMINATJN, BETWEEN KEYNESIAN AND CLASSICAL TIIEORIES OF THE BUSINESS CYCLE; JAPAN 1967-1982

8416C Deardorff, Alan V. FIRless FIRwoes: HOW PREFERENCES CAN INTERFERE WITH THE THEOREMS OF INTERNATIONAL TRADE.

$8417 \mathrm{C}$ Greenwood, Jeremy. NONTRADED GOODS, THE TRADE BALANCE, AND THE BALANCE OF PAYRENTS.

8418C Blomqvist, Ake and Sharif Mohammad. CONTROLS, CORRUPTION, AND COMPETITIVE RENT-SEEKING IN LDCs.

8419C Grossman, Herschel I. POLICY, RATIONAL EXPECTATIONS, AND POSITIVE ECONOMIC ANALYSIS.

8420C Garber, Peter M. and Robert G. King. DEEP STRUCTURAL EXCAVATION? A CRITIOUUE OF EULER EQUATION METHODS.

8421C Barro, Robert J. THE BEHAVIOR OF U.S. DEFICITS.

8422C Persson, Torsten and Lars E.0. Svensson. INTERNATIONAL BORROWING AND TIME-CONSISTENT FISCAL POLICY.

8423C Obstfeld Maurice. CAPItAL CONTROLS, THE DUAL EXCHANGE RATE, AND DEVALUATION.

8424C Kuhn, Peter. UNION PRODUCTIVITY EFFECTS AND ECONOMIC EFFICIENCY.

8425C Hamilton, Bob and John Whalley. TAX TREATMENT OF HOUSING IN A DYNAMIC SEOUENCED GENERAL EỌUILIBRIUM MODEL.

$\because 426 \mathrm{C}$ Hamilton, Bob, Sharif Mohammad, and John Whalley. RENT SEEKING AND THE NORTH-SOUTH TERMS OF TRADF.

$8427 \mathrm{C}$ Adams, Charles and Jeremy Greenwood. DUAL EXCHANGE RATE SYSTEMS AND CAPITAL CONTROLS: AN INVESTIGATION.

8428 Loh, Choon Cheong and Michael R. Veall. A NOTE ON SOCIAL SECURITY AND PRIVATE SAVINGS IN SINGAPORE.

8429 Whalley, John. REGRESSION OR PROCRESSION: THE TAXING OUESTION OF INCIDENCE ANALYSIS.

3430 Kuhn, Peter. WAGES, EFFORT, AND INCENTIVE-COMPATIBILITY IN LIFE-CYCLE EMPLOYMENT CONTRACTS. 
8431 Greenwood, Jeremy and Kent P. Kimbrough. AN INVESTIGATION IN THE THEORY OF FOREIGN EXCHANGE CONTROLS.

8432 Greenwood, Jeremy and Kent P. Kimbrough. CAPITAL CONTROLS AND THE INTERNATIONAL TRANSMISSION OF FISCAL POLICY.

8433 : Nguyen, Trien Trien and John Whalley. EỌUILIBRIUM UNDER PRICE CONTROLS WITH ENDOSENOUS TRANSACTIONS COSTS.

8434 Adams, Charles and Russell S. Boyer. EFFICIENCY AND A SIMPLE MODEL OF EXCHANGE RATE DETERMINATION.

8435 Kuhn, Peter. UNIONS, ENTREPRENEURSHIP, AND EFFICIENCY.

8436 Hercowitz, Zv1 and Efraim Sadka. ON OPTIMAL CURRENCX. SUBSTITUTION POLICY AND PUBLIC PINANCE.

8437 Lenjosek, Gordon and John Whalley. POLICY EVALUATION IN A SMALL OPEN PRICE TAKING ECONOMY: CANADIAN ENERGY POLICIES.

8438 Aschauer, David and Jeremy rreenwood. MACROECONOMIC EFFECTS OF FISCAL POLICY.

8439C Hercowitz, Zvi. ON THE DETERMINATION OF THE EXTERNAL DEBT: THE CASE OF ISRAEL.

8440C Stern, Robert M. GLOBAL DIMENSIONS AND DETERMINANTS OF INTERNATIONAL TRADE AND INVESTMENT IN SERVICES.

$8441 \mathrm{C}$ Deardorff, Alan V. COMPARATIVE ADVANTAGE AND INTERNATIONAL TRADE AND INVESTMENT IN SERVICES.

8442C Daly, Donald J. TECHNOLOGY TRANSFER AND CANADA'S COMPETITIVE PERFORMANCE.

8443C Grey, Rodney de C. NEGOTIATING ABOUT TRADE AND INVESTMENT IN SERVICES.

8444C Grossman, Gene M. and Carl Shapiro. NORMATIVE ISSUES RAISED BY INTERNATIONAL TRADE IN TECHNOLOGY SERVICES.

3445C Chant, John F. THE CANADIAN TREATMENT OF FOREIGN BANKS: A CASE STUDY IN THE WORKINGS OF THE NATIONAL TREATMENT APPROACH.

8446C Aronson, Jonathan D. and Peter F. Cowhey. COMPUTER, DATA PROCESSING, AND COMMUNICATION SERVICES.

8447C Feketekuty, Geza. NEGOTIATING STRATEGIES FOR LIBERALIZING TRADE AND INVESTMENT IN SERVICES.

8448C Harrison, Glenn, W. and E.E. Rutstrom. THE EFFECT OF MANUFACTURING SECTOR PROTECTION ON ASEAN AND AUSTRALIA: A GENERAL ENUIL IBRIUM ANALYSIS. 
$8501 C$

8502C Horstmann, Ignatius and James R. Markusen. UP YOUR AVERAGE COST CURVE: INEFFICIENT ENTRY AND THE NEW PROTECTIONISM.

8503C Gregory, Allan $甘$. TESTING INTEREST RATE PARITY AND RATIONAL EXPECTATIONS FOR CANADA AND THE UNITED STATES.

8504C Kuhn, Peter and Ian Hooton. INTERNATIONAL FACTOR MOVEMENTS IN THE PRESENCE OF A FIXED FACTOR. 